\title{
ANALISIS FIX OVERTIME UNTUK MENINGKATKAN KINERJA DINAS JAGA ABK KAPAL MT. SEPINGGAN DI PT. PERTAMINA (PERSERO) PERKAPALAN JAKARTA
}

\author{
Andri Kurniawan ${ }^{\mathrm{a}}$, Sri Purwantini ${ }^{\mathrm{b}}$ dan Arika Palapa ${ }^{\mathrm{c}}$ \\ ${ }^{\mathrm{a}}$ Taruna (NIT.50135044.K) Program Studi KALK PIP Semarang \\ ${ }^{\mathrm{b}}$ Dosen Program Studi KALK PIP Semarang \\ ${ }^{c}$ Dosen Program Studi Nautika PIP Semarang
}

\begin{abstract}
ABSTRAK
Kapal telah menjadi pilihan utama angkutan laut dalam pendistribusian barang antar pulau, maupun antar Negara. Hal tersebut tak lepas dari kinerja awak kapal yang bekerja menangani muatan kapal sehingga terlaksana dengan efektif dan efisien. Salah satu tugas tanggung jawab awak kapal adalah dinas jaga. Berdasarkan hasil konduite yang dilakukan terhadap awak kapal MT Sepinggan pada tahun 2015 terjadi penurunan kinerja dinas jaga awak kapal karena adanya overtime yang disebabkan oleh beberapa faktor. Terlebih adanya kebijakan fix overtime pada PT Pertamina. Dalam penelitian ini peneliti menggunakan metode kualitatif yang menghasilkan data deskriptif berupa kata-kata tertulis dari orangorang dan perilaku yang diamati dengan mengumpulkan data berupa pendekatan terhadap obyek melalui observasi, wawancara secara langsung terhadap subyek serta menggunakan dokumen dan data yang berhubungan dengan dinas jaga ABK.

Hasil penelitian menunjukkan bahwa beberapa hal yang mempengaruhi overtime antara lain adalah adanya peran muka belakang, drill, lego jangkar, perawatan mesin kapal. Vessel Allowance, Insentif, Pemberian gaji tepat waktu yang dilakukan oleh PT Pertamina guna meningkatkan kinerja dinas jaga disamping adanya kebijakan fix overtime, dan upaya yang dilakukan untuk meningkatkan dinas jaga adalah memberikan motivasi dan menerapkan kebijakan overtime.
\end{abstract}

\section{Kata kunci : fix overtime, overtime, kinerja, dinas jaga}

\section{PENDAHULUAN}

Indonesia merupakan Negara kepulauan yang terdiri dari pulau-pulau yang dihubungkan dengan lautan. Hal tersebut menyebabkan sarana angkutan laut menjadi pilihan utama untuk proses pendistribusian barang antar pulau. Pada industri pelayaran saat ini, diketahui bahwa kapal merupakan sarana angkutan laut yang sangat dibutuhkan untuk menunjang kelancaran pengangkutan barang dari satu tempat ke tempat lain yang dapat dilakukan menggunakan berbagai sarana transportasi. Kapal dipilih sebagai sarana angkutan laut yang utama karena pengiriman barang dapat dilaksanakan dalam jumlah yang besar sedangkan biaya yang dikeluarkan lebih kecil di bandingkan dengan sarana angkut yang lain.

Pada dasarnya, sarana transportasi laut lebih cenderung mengutamakan penanganan muatan yang lebih efektif dan efisien. Agar hal tersebut dapat terlaksana dengan baik, dibutuhkan rasa tanggung jawab serta etos kerja yang tinggi dalam diri para perwira ataupun anak buah kapal. Setiap perwira khususnya perwira deck harus mengerti tentang aturan-aturan jaga atau biasa disebut dengan dinas jaga/tugas jaga kapal. Dinas jaga adalah suatu kegiatan pengawasan selama 24 (dua puluh empat) jam di atas kapal, yang dilakukan dengan tujuan mendukung operasi 
Analisis Fix Overtime Untuk Meningkatkan Kinerja Dinas Jaga ABK Kapal MT. Sepinggan Di PT. Pertamina (Persero) Perkapalan Jakarta

Andri Kurniawan, Sri Purwantini dan Arika Palapa

pelayaran supaya terlaksana dengan selamat. Hal ini dilakukan dengan mengondisikan pelayaran supaya dapat berjalan dengan kewaspadaan sesuai dengan kaidah keselamatan pelayaran, yang didalamnya memuat antara lain kegiatan pengamatan kondisi keliling kapal sesuai dengan Peraturan Pencegahan Tubrukan di Laut (P2TL). (Krisdiana, 2007).

Tugas jaga laut dilakukan di anjungan kapal, regu jaga terdiri dari perwira tugas jaga, juru mudi jaga. Sesuai dengan aturan jaga yang telah ditetapkan organisasi di atas kapal, semua awak kapal wajib melaksanakan aturan tersebut tanpa terkecuali. Organisasi ini harus mencerminkan suasana yang kondusif dan mampu menunjang tercapainya suasana kerja yang nyaman bagi seluruh awak kapal. Pada pelaksanaan tugas jaga saat kapal sedang berlayar, diperlukan ketelitian, kewaspadaan, tanggung jawab, dan kedisiplinan yang tinggi. Hal tersebut harus dilaksanakan dan ditaati oleh seluruh awak kapal khususnya bagian deck agar tidak terjadi bahaya-bahaya navigasi (kandas, drifting atau hanyut, cuaca buruk) ataupun bahaya-bahaya lain seperti, bahaya tubrukan kapal, pencemaran, kebakaran, pencurian atau pembajakan, kecelakaan, dll.

Pengamatan yang cermat perlu dilakukan oleh setiap regu dinas jaga agar dapat mengantisipasi situasi secara dini serta membuat penilaian yang tepat terhadap situasi maupun perubahan situasi, yang berkaitan dengan keamanan dan keselamatan kapal terhadap bahaya-bahaya yang timbul setiap saat. Pentingnya jaminan keselamatan transportasi, dalam hal ini jaminan berupa sistem yang baku tersistematisasi dan mudah dimengerti serta dilaksanakan oleh semua petugas sangat diperlukan. Hal tersbut dijelaskan dalam penelitian yang dilakukan oleh Benny Agus S. M. (2010) yang berjudul pengaruh safety equipment terhadap keselamatan berlayar. Jaga laut pada umumnya dilaksanakan pada saat sedang berlayar, sandar maupun bongkar ataupun muat muatan. Pada saat bongkar ataupun muat tugas jaga dilakukan secara bersama oleh seluruh ABK maupun perwira meskipun bukan merupakan jam dinas jaganya. Oleh karna itu, terkadang menyebabkan pelaksanaan dinas jaga tidak dilakukan dengan sungguh-sungguh dan cenderung menurun.

Pertukaran jaga dilakukan dengan serah terima dari perwira jaga kepada penggantinya, perwira jaga maupun juru mudi jaga akan membangunkan setengah jam sebelumnya. Setelah berada di anjungan, perwira ataupun $\mathrm{ABK}$ jaga harus melihat anjungan kapal, lampu suar, perintah Nakhoda, membiasakan diri dengan situasi yang ada. Perwira yang diganti menyerahkan jaganya dengan memberikan informasi yang diperlukan seperti posisi terakhir, cuaca, kapal lain dan hal-hal yang dipandang perlu. Sebagai catatan, bagi perwira jaga yang telah selesai melakukan serah terima dinas jaga diwajibkan meronda kapal terutama pada malam hari, seperti pemeriksaan lubang untuk masuk tangki atau main hole, pipa sounding, kran-kran air, cerobong asap dan lain-lain.

Salah satu penyebab terjadinya bahayabahaya yang mungkin terjadi di atas kapal disebabkan kesalahan atau kelalaian Perwira jaga maupun juru mudi jaga seperti kandas, kebakaran, kapal mengalami tubrukan dan sebagainya. Kesalahan dan kelalaian yang terjadi dapat diakibatkan karena tidak seriusnya tugas dalam melaksanakan dinas jaga. Faktor-faktor yang mempengaruhi kinerja para petugas jaga, salah satunya adalah penghasilan/gaji. Supartini (2010) menjelaskan dalam penelitianya bahwa penilaian prestasi kerja secara obyektif, penempatan karyawan sesuai dengan keahlian, pemberian insentif dan kompensasi seperti memberikan imbalan atas jasa yang diberikan kepada perusahaan seperti kompensasi yang berupa barang dan tunjangan dapat menjadi 
motivasi guna meningkatkan kinerja dan prestasi kerja bawahan di perusahaan pelayaran. Maka dari itu, tidak adanya tambahan penghasilan di luar jaga yang semestinya memungkinkan terjadinya penurunan kinerja crew yang sedang dinas jaga.

Dalam pembahasan masalah penelitian, maka dirumuskan permasalahannya sebagai berikut:

1. Apakah faktor penyebab munculnya Overtime pada kapal MT. Sepinggan PT. Pertamina (Persero) Perkapalan Jakarta ?

2. Bagaimana kebijakan PT. Pertamina (Persero) Perkapalan Jakarta mengelola Fix Overtime pada MT. Sepinggan?

\section{KAJIAN PUSTAKA}

\section{Pengertian waktu kerja lembur (Overtime)}

Pasal 1 ayat 1 Peraturan Menteri No. 102/MEN/VI/2004 menerangkan bahwa waktu kerja lembur atau overtime adalah waktu kerja yang melebihi 7 jam sehari untuk 6 hari kerja dan 40 jam dalam seminggu atau 8 jam sehari untuk 8 hari kerja dan 40 jam dalam seminggu atau waktu kerja pada hari istirahat mingguan dan atau pada hari libur resmi yang ditetapkan Pemerintah. Feri Harianto dan M. Syafiudin (2008:3) kerja lembur adalah suatu jenis kerja yang dilaksanakan diluar jam kerja normal, dan upah yang diterima oleh pekerja berbeda dengan upah resmi pada kerja normal.

Pasal 3 Peraturan Menteri No. 102/MEN/VI/2004 tentang Waktu Kerja Lembur dan Upah Kerja Lembur menyatakan secara tegas bahwa waktu Kerja Lembur hanya dapat dilakukan paling banyak 3 (tiga) jam dalam 1 (satu) hari dan 14 (empat belas) jam dalam 1 (satu) minggu".

Pasal 7 Peraturan Menteri No. 102/ MEN/VI/2004 mengemukakan bahwa perusahaan yang mempekerjakan pekerja/buruh selama waktu kerja lembur berkewajiban :

a. Membayar upah kerja lembur;

b. Memberi kesempatan untuk istirahat secukupnya;

c. Memberikan makanan dan minuman sekurang-kurangnya 1.400 kalori apabila kerja lembur dilakukan selama 3 (tiga) jam atau lebih. (Pemberian makan dan minum sebagaimana dimaksud tidak boleh diganti dengan uang).

\section{Pengertian Kinerja}

Dewi Sartika Mathan dan Sofia Achnes (2013:144) mengungkapkan bahwa kinerja merupakan hasil kerja secara kualitas dan kuantitas yang dicapai oleh seorang pegawai dalam melaksanakan tugasnya sesuai dengan tanggung jawab yang diberikan kepadanya.

Adapun faktor-faktor yang mempengaruhi kinerja adalah :

a. Efektifitas dan efisensi;

b. Wewenang;

c. Disiplin;

d. Inisiatif.

\section{Pengertian Anak Buah Kapal}

Dalam Undang-undang tentang Pelayaran No. 17/2008, Anak buah kapal adalah awak kapal selain Nakhoda. Awak kapal adalah orang yang bekerja atau di pekerjakan di atas kapal oleh pemilik atau operator kapal untuk melakukan tugas di atas kapal sesuai dengan jabatan yang tercantum dalam buku sijil, termasuk Nakhoda.

Anak buah kapal mempunyai beberapa tugas, antara lain sebagai berikut :

a. 15 menit sebelum pergantian jaga juru mudi lama yang bertugas segera membiritahukan perwira dan juru mudi jaga baru;

b. Apabila kapal sudah berada di laut lepas segara bendera Republik Indonesia diturunkan atau kapal 
Andri Kurniawan, Sri Purwantini dan Arika Palapa

sudah berada di luar jangkauan, begitu juga dengan bendera negara atau bendera lainnya, agar tetap bendera itu tidak cepat rusak;

c. Pada jam 18.00 lampu jalan sudah harus dinyalakan;

d. Dalam situasi apapun juru mudi jaga pagi jam 08.00 sampai dengan 12.00 sudah harus bangun lebih awal untuk membersihkan anjungan meja dan kacanya dilap, kamar perwira dan kamar crew disapu kemudian dipel;

e. Juru mudi jaga siang hari jam 12.00 s/d 16.00 setelah melakukan tugas jaga harus segera membersihkan seluruh ruangan sesuai poin no $4 \mathrm{di}$ atas dan piring, gelas beserta botol aqua dibawa turun untuk dicuci bila sudah selesai aplosan jaga;

f. Apabila dalam pelayaran di laut atau di sungai yang bertugas mendapat berita penting baik itu dari kantor, kapal-kapal dan keadaan lain yang dianggap penting segera diberitahukan ke nakhoda/perwira jaga baru;

g. Yang bertugas jaga baik itu perwira atau juru mudi dan siapapun bila yang berada di anjungan harus menjaga kebersihan di dalam dan luar anjungan;

h. Dilarang membuang debu atau puntung rokok di dalam anjungan dan di luar anjungan (menghamburkan debu-debu rokok di meja kemudi);

i. Yang bertugas jaga menjaga perlengkapan untuk tidak dihamburhamburkan dan selalu diatur dengan rapih pada tempatnya;

j. Tidak diperkenankan menggunakan handphone selama melakukan tugas jaga terutama kapal melakukan pelayaran di alur/sungai;

k. Saat melakukan tugas jaga harus berpakaian sopan atau siapapun yang naik ke atas anjungan;

1. Bagi juru mudi yang memegang kemudi agar supaya membalas aba- aba dari perwira atau pandu bila kapal berada di alur yang dilalui. Apabila kapal sudah tiba di tujuan dan sudah selesai sandar atau anchor, juru mudi yang masih bertugas langsung membereskan seluruh peralatan di anjungan, serta memantau keadaan sekeliling kapal dan melihat/catat orang-orang yang naik ke atas kapal.

\section{Pengertian Dinas Jaga}

Menurut Krisdiana (2007:245). Dinas jaga adalah suatu kegiatan pengawasan selama 24 (dua puluh empat) jam di atas kapal, yang dilakukan dengan tujuan mendukung operasi pelayaran supaya terlaksana dengan selamat. Ini dilakukan dengan mengondisikan pelayaran supaya dapat berjalan dengan kewaspadaan sesuai dengan kaidah keselamatan pelayaran, yang didalamnya memuat antara lain kegiatan pengamatan kondisi keliling kapal sesuai dengan Peraturan Pencegahan Tubrukan di Laut (P2TL).

\section{Kerangka Pikir Penelitian}

Untuk dapat memaparkan pembahasan penelitian ini, peneliti membuat suatu kerangka pemikiran terhadap hal-hal yang menjadi pembahasan mengenai masalah penelitian ini. 


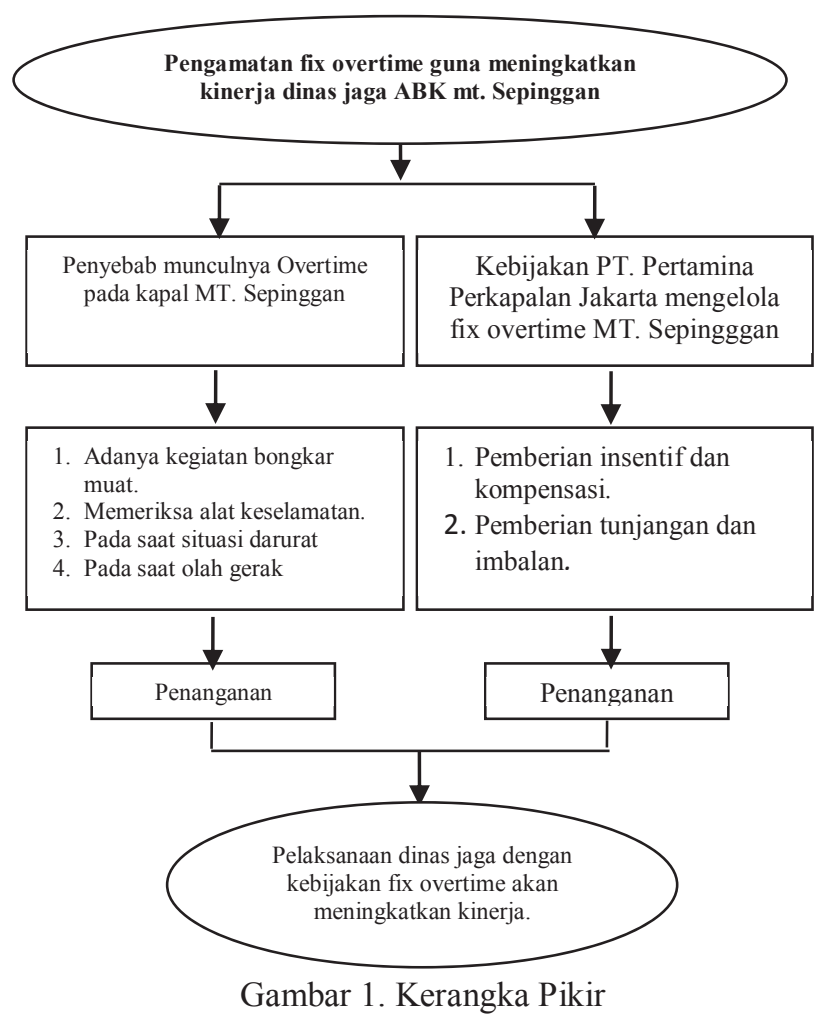

III. METODOLOGI

\section{A. Metode Penelitian}

Metode penelitian pada dasarnya merupakan cara ilmiah untuk mendapatkan data dengan tujuan dan kegunaan tertentu (Sugiyono, 2015:2). Dari istilah ini, dapat diketahui bahwa peran penting metodologi penelitian untuk memberikan keterangan tentang apa dan bagaimana penelitian dilakukan bagi seorang peneliti.

Dari uraian di atas, dapat diketahui peran penting metodologi penelitian untuk memberikan keterangan tentang apa dan bagaimana penelitian dilakukan bagi seorang peneliti. Dengan dasar seperti itu peneliti akan memaparkan pengalaman dan ilmu yang diperoleh selama penelitian di PT. Pertamina.

Menurut Juliansyah Noor (2010:33), pendekatan kulitatif adalah suatu proses penelitian dan pemahaman yang berdasarkan metodologi yang menyelidiki suatu fenomena social dan masalah manusia. Pada pendekatan ini, peneliti menekankan sifat realitas yang terbangun secara social, hubungan erat antara peneliti dan subject yang diteliti.

Melalui penelitian manusia dapat menggunakan hasilnya. Secara umum data yang telah diperoleh dari penelitian dapat digunakan untuk memahami, memecahkan dan mengantisipasi masalah.

Dalam penelitian, peneliti memilih untuk melakukan penelitian melalui metode kualitatif, karena akan menyajikan data-data yang diperoleh secara deskriptif atau membuat gambaran mengenai situasi atau kejadian berdasarkan data-data yang akurat dan memiliki hubungan erat antara peneliti dengan yang diteliti.

\section{B. Teknik Pengumpulan Data}

Dalam penulisan penelitian, data dan informasi yang lengkap, objektif dan dapat dipertanggung jawabkan sangatlah diperlukan untuk dapat diolah dan diteliti guna mendapatkan suatu gambaran yang benar dan jelas mengenai pemecahan masalah yang dibahas. Dalam rangka mengumpulkan data dalam penelitian ini, dilakukan beberapa teknik pengumpulan data, diantaranya sebagai berikut:

\section{Observasi}

Kegiatan observasi meliputi pencatatan secara sistematik kejadian-kejadian perilaku, obyekobyek yang dilihat dan hal-hal lain yang diperlukan dalam mendukung penelitian yang sedang dilakukan (Sarwono, 2006, p. 224). Peneliti melaksanakan observasi di atas kapal MT. Sepinggan dengan melakukan pencatatan data dalam penelitian.

\section{Wawancara}

Menurut Sugiono (2015, p. 231) wawancara adalah suatu cara pengumpulan data yang digunakan untuk memperoleh informasi langsung dari sumbernya. Wawancara merupakan proses tanya jawab secara lisan yang dilakukan 
Analisis Fix Overtime Untuk Meningkatkan Kinerja Dinas Jaga ABK Kapal MT. Sepinggan Di PT. Pertamina (Persero) Perkapalan Jakarta

Andri Kurniawan, Sri Purwantini dan Arika Palapa

seseorang, saling berhadapan dan saling menerima serta memberi informasi. Pelaksanaan wawancara dilakukan dengan para awak kapal atau crew MT. Sepinggan, seperti Chief Officer, Second Officer, Third Officer, Bosun serta para A/B kapal dengan menggunakan metode terpimpin, yaitu pewawancara membuat kerangka dan garis besar pokok-pokok pertanyaan, antara lain tentang kapal dan muatan biji besi, prosedur pembersihan ruang muat, serta kendala yang dihadapi dan cara mengatasinya.

\section{Dokumentasi}

Menurut Sugiyono (2015:240) teknik dokumentasi yaitu cara pengumpulan data melalui gambar, arsip-arsip termasuk juga buku-buku tentang pendapat, teori, dalil-dalil atau hukum-hukum dan lain-lain. Untuk menunjang penulisan penelitian ini, peneliti melaksanakan dokumentasi berkaitan dengan permasalahan. Artinya dilakukan pengumpulan semua dokumen dan data-data yang berkaitan dengan masalah penelitian tentang fix overtime di PT. Pertamina (Persero) Perkapalan Jakarta.

\section{Studi Pustaka}

Dari melakukan teknik reduksi pengumpulan data secara observasi dan dokumentasi disadari bahwa data-data yang didapat tidaklah lengkap tanpa melakukan penelitian secara studi pustaka. Studi pustaka dilakukan untuk mendapat informasiinformasi mengenai permasalahan yang diteliti, dalam melaksanakan studi pustaka terdapat informasi yang diambil dari buku-buku yang ada di berbagai sumber yang ada. Tidak hanya itu, untuk lebih menunjang penelitian ini informasi dan data penelitian juga didapat dari buku yang tersedia di perpustakaan
Politeknik Ilmu Pelayaran semarang, meskipun buku yang tersedia belum lengkap, namun informasi yang didapat cukup umtuk mendukung penulisan ini.

\section{DISKUSI}

\section{A. Gambaran Umum Objek Penelitian}

Perkapalan Pertamina dimulai dengan dibentuknya Divisi Perkapalan Pertamina pada tahun 1959. Dengan armada dua unit kapal tanker draft rendah berkapasitas 3.220 DWT yang didapatkan dengan skema bare boat hire purchase (BBHP) atau sewa-beli jangka panjang dari PT. Caltex. (Peraturan Pemerintah No. 11 th 1975)

Seiring dengan berjalannya waktu, pada tanggal 6 Desember 1975, Presiden Soeharto mengeluarkan Dekrit Nomor 44, yang mengatur lebih lanjut keberadaan Direktorat Perkapalan dan Telekomunikasi (Dit. P\&T). Dalam kurun waktu inilah, Dit. P\&T mencapai masa kejayaan dengan mengelola 133 unit kapal berbagai ukuran, dengan komposisi 77 unit tanker merupakan kapal milik sendiri, sedang kapal yang disewa dari pihak lain tidak lebih 60 unit. Selain itu Perkapalan juga mengelola 134 Pelabuhan Khusus (Pelsus) minyak dan gas, yang tersebar di seluruh Nusantara juga di bawah pengelolaan Dit. P \& T. Serta seluruh sarana komunikasi elektronik kepunyaan Pertamina.

Pada tanggal 15 Maret 1990 dikeluarkan Dekrit Presiden No 11 yang diikuti oleh restrukturisasi organisasi dengan dibentuknya organisasi baru yakni Direktorat Perkapalan, Kebandaraan dan Komunikasi (Dit. PKK). Keberadaan kapal milik pun kian menyusut yang semula dari 70 -an unit menjadi 45 unit saja.

Tahun 2000 merupakan awal perubahan Pertamina. Dengan adanya 
Dekrit Presiden No 169/2000 tanggal 7 Desember 2000 mendorong lahirnya organisasi baru, PT. PERTAMINA (PERSERO) tepat pada tanggal 1 Januari 2001. Sejak saat itu mulailah transformasi secara menyeluruh di PT. PERTAMINA (PERSERO), tak terkecuali Perkapalan Pertamina.

Melalui dekrit ini nama Direktorat Perkapalan, Kebandaran dan Komunikasi, diubah menjadi Perkapalan Pertamina. Pada saat itu, Perkapalan Pertamina mengoperasikan 180 unit kapal (termasuk 9 trayek COA, \pm 20 kapal.

Pasca lahirnya UU Migas yang baru, Pertamina bertransformasi melakukan berbagai pembenahan. Sejak saat itu mulailah transformasi secara menyeluruh di Pertamina, tak terkecuali Perkapalan Pertamina, yang ingin menjadi bagian dari perusahaan berkelas dunia. Konsekuensinya, mau tak mau tata kelola Perkapalan harus dibenahi pula, seperti divisi lainnya dalam tubuh Pertamina. Direktorat Perkapalan, Kebandaran dan Komunikasi, diubah menjadi Perkapalan Pertamina, menjadi bagian Direktorat Hilir. Kemudian organisasi Direktorat Hilir dipecah menjadi Direktorat Pengolahan dan Direktorat Pemasaran Niaga, dengan struktur organisasi sebagai berikut.

\section{B. Hasil Penelitian}

Menurut Krisdiana (2007:245). Dinas jaga adalah suatu kegiatan pengawasan selama 24 (dua puluh empat) jam di atas kapal, yang dilakukan dengan tujuan mendukung operasi pelayaran supaya terlaksana dengan selamat. Dinas jaga di MT. Sepinggan dilaksanakan 4 (empat) jam selama bergantian antara anak buah kapal sehingga kapal dapat beroperasi dengan baik. Adapun periode dinas jaga MT. Sepinggan yang telah diatur adalah 00.00-04.00, 04.00-08.00, 08.00-12.00 dan seterusnya. Hal ini sesuai dengan teori yang dikemukakan oleh Krisdiana (2007:245). Namun pada kapal MT.
Sepinggan terjadi masalah yang berkaitan dengan dinas jaga sehingga terjadi Overtime. Overtime adalah waktu kerja yang melebihi 7 jam dalam sehari untuk 6 hari kerja dan 40 jam dalam seminggu. Pada MT. Sepinggan Overtime terjadi karena beberapa hal sebagai berikut :

\section{Peran muka belakang ketika sandar atau lepas sandar}

Peran muka belakang yang berada di anjungan dan di buritan yang selalu mengawasi jalannya proses sandar atau lepas sandar kapal. Dan selalu siap untuk menerima atau melempar tali tros yang akan diikatkan pada kapal. Pada kapal MT. Sepinggan, yang bertugas untuk melempar atau menerima tali tros yang akan dikaitkan pada kapal adalah Bosun dan Juru mudi. Tali tros berfungsi agar kapal tidak bergerak menjauhi dermaga. Pada kapal MT. Sepinggan peran muka belakang bekerja tidak mengenal waktu, peran muka belakang bekerja sesuai dengan jadwal kapal akan sandar. Jika Bosun mendapatkan jaga pada jam 12.00 16.00 dan waktu sandar jam 17.00 maka bosun tetap turun ke lapangan untuk membantu menyandarkan kapal dan overtime terjadi.

\section{Adanya lego jangkar}

Lego jangkar merupakan kegiatan untuk membatasi pergerakan dari kapal itu sendiri, seperti kapal akan masuk pelabuhan dan harus menunggu giliran untuk masuk pelabuhan tersebut. Pada MT. Sepinggan lego jangkar dilaksanakan pada saat kapal akan memasuki wilayah perairan dan akan melakukan bongkar muat di dermaga. Pada saat lego jangkar Bosun dan Juru mudi melakukan persiapan penurunan jangkar. Pada saat lego jangkar tidak mengenal jam jaga mereka. Jadi kapanpun lego jangkar dilaksanakan Bosun dan Juru mudi harus siap. 
Analisis Fix Overtime Untuk Meningkatkan Kinerja Dinas Jaga ABK Kapal MT. Sepinggan Di PT. Pertamina (Persero) Perkapalan Jakarta

Andri Kurniawan, Sri Purwantini dan Arika Palapa

Maka pada saat lego jangkar terjadilah overtime.

\section{Adanya bongkar muat muatan}

Bongkar muat muatan merupakan satu kegiatan yang dilakukan dalam proses pengiriman barang yang dilakukan di dermaga. Proses bongkar muat di MT. Sepinggan memerlukan pengawasan yang dilakukan Chief Officer yang beperan sebagai penghitung muatan. Tujuan pengawasan untuk mempertahankan keutuhan muatan dan menghindari pencurian muatan.

\section{Adanya Drill}

Dalam menjaga keamanan dan keselamatan di atas kapal, program keterampilan atau simulasi dalam mempergunakan peralatan keselamatan, kebakaran, atau pencegahan pencemaran lingkungan untuk mengatasi keadaan darurat. Kegiatan drill dilakukan secara terusmenerus dan berulang-ulang untuk meningkatkan keterampilan. Pada kapal MT. Sepinggan, drill dilakukan minimal 1 (satu) bulan sekali dan waktu drill sesuai perintah Nakhoda. Maka overtime pada saat drill sering terjadi.

\section{Adanya Bungkering (pengisian} bahan bakar)

Proses pengisian bahan bakar pada kapal melalui proses yang biasanya dilakukan secara ship to ship. Ship to ship adalah kegiatan 2 (dua) kapal yang sedang melakukan pengisian bahan bakar dari kapal bungker menuju kapal pengguna. Pada kapal MT. Sepinggan pengisian bahan bakar tidak memerlukan waktu yang cukup lama, tetapi semua anak buah kapal khususnya Engine Department bekerja untuk pengisian bahan bakar. Kepala kamar mesin mengawasi jalannya pengisian sedangkan Mandor membuka tutup kran pengisian bahan bakar.

\section{Pemeliharaan mesin kapal}

Pemeliharaan mesin kapal adalah suatu kegiatan rutin yang dilakukan anak buah kapal untuk menjaga performa kapal tersebut. Karena pembuatan kapal MT. Sepinggan pada tahun 1982 maka perlu perawatan yang serius. Banyak terjadi kerusakan-kerusakan pada mesin dan peralatan lainnya.

\section{Pembahasan}

Pada bab ini peneliti akan menjelaskan mengenai fix overtime guna meningkatkan kinerja dinas jaga ABK kapal MT. Sepingan. Selama peneliti melakukan penelitian di PT. Pertamina terdapat beberapa faktor penyebab munculnya overtime di MT. Sepinggan antara lain:

\section{Penyebab munculnya fix overtime}

a. Peran muka belakang ketika sandar atau lepas sandar

Peran muka belakang pada saat sandar atau lepas sandar adalah proses kapal akan sandar dan crew standby berada di haluan serta buritan untuk menyiapkan tali-tali tros sampai kapal tiba di dermaga. Berdasarkan observasi dan diperkuat penjelasan dari salah satu narasumber, "Peran muka belakang tugasnya itu menjaga haluan dan buritan pas mau sandar atau lepas sandar. Saya pasti yang jalanin itu, dari melempar tali sampai menangkap tali". (hasil wawancara dengan Bapak Suratman selaku bosun, tanggal 14 Maret 2017). Pada saat proses, muka belakang yang berada di haluan adalah Bosun, Juru mudi, serta Mualim I. sedangkan yang berada di anjungan adalah Kapten, Mualim III, Juru mudi dan Pandu, serta yang berada di buritan Mualim II dan juru mudi. Jika proses sandar jam 10.00 LT maka 
yang berada di luar jam jaga 08.00-12.00 maka dikatakan fix overtime karena mereka bekerja di luar jam jaga. Hal yang harus disiapkan pada saat persiapan sandar dan lepas sandar adalah menyiapkan tali-tali tros, mengirimkan tali ke darat untuk diikatkan pada bolder darat, memasang rat guard, memasang fire wire ketika kapal akan berangkat tali digulung.

\section{b. Lego jangkar}

Lego jangkar merupakan bagian dari sistem tambat kapal yang berfungsi untuk membatasi gerak kapal pada waktu berlabuh di luar pelabuhan, agar kapal tetap pada kedudukannya meskipun mendapat tekanan oleh arus laut, angin, gelombang dan sebagainya, selain itu juga berguna untuk membantu penambatan kapal pada saat yang diperlukan sebelum kapal memasuki dermaga yang ditunjuk. Pada kapal MT. Sepinggan lego jangkar, Bosun dan juru mudi yang harus menyiapkan peralatan dan siap menurunkan jangkar. Fakta ini diperkuat dari wawancara yang dilakukan dengan salah satu narasumber "kegiatan saya banyak seperti lego jangkar. Lego jangkar pun yang mengerjakan saya. Paling dibantu sama juru mudi". (hasil wawancara dengan Bapak Suratman selaku bosun, tanggal 14 Maret 2017).

\section{c. Adanya bongkar muat muatan di dermaga}

Bongkar muat muatan merupakan satu kegiatan yang dilakukan dalam proses pengiriman barang. Berdasarkan observasi di lapangan dan diperkuat penjelasan dari Bapak Muhammad Chamdanie selaku Crew kapal MT. Sepinggan sebagai Chief Officer yang dijumpai, adanya bongkar muat yang dilakukan maka tidak sedikit yang harus ikut mengawasi proses bongkar muat. Maka dari itu diperlukan Anak buah kapal yang harus overtime. Tugas yang harus dilakukan adalah Menghitung Rate per jam, keliling di anjungan selama bongkar muat, standby radio jika sewaktu-waktu ada perintah dari darat. Adapun wawancara dengan narasumber "Semua anak buah kapal harus ikut dalam kegiatan bongkar muat, dari Mualim III, bosun, juru mudi, kelasi ikut semua". (hasil wawancara dengan Bapak Muhammad Chamdanie selaku Chief Officer, tanggal 1 Maret 2017).

\section{d. Drill}

Dalam menjaga keamanan dan keselamatan di atas kapal, program keterampilan atau simulasi dalam mempergunakan peralatan keselamatan, kebakaran, atau pencegahan pencemaran lingkungan untuk mengatasi keadaan darurat. Kegiatan drill dilakukan secara terus-menerus dan berulang-ulang untuk meningkatkan keterampilan. Pada MT. Sepinggan drill dilakukan minimal 1 (satu) bulan sekali pada akhir bulan untuk meningkatkan kemampuan dan kecepatan pada anak buah kapal. Sebelum drill dilakukan anak buah kapal tidak mengetahui tentang perencanaan drill karena simulasi drill direncanakan oleh kapten kapal. Seperti yang diutarakan oleh salah satu narasumber "waktu drill kita tidak ditentukan, tergantung kondisi. Bisa malam hari atau siang hari. Biasanya itu pada akhir bulan. Otomatis kita kalo ada alarm bunyi kita harus bergegas menyelamatkan diri dari bahaya- 
Analisis Fix Overtime Untuk Meningkatkan Kinerja Dinas Jaga ABK Kapal MT. Sepinggan Di PT. Pertamina (Persero) Perkapalan Jakarta

Andri Kurniawan, Sri Purwantini dan Arika Palapa

bahaya yang ada, seperti kebakaran, abandon ship". (hasil wawancara dengan Bapak Suratman selaku Bosun, tanggal 14 Maret 2017)

Beberapa program Drill dan latihan yang harus dilakukan, antara lain:

\section{1) Kebakaran}

Minimal dilakukan satu bulan sekali atau apabila terjadi penggantian lebih dari dua puluh lima persen jumlah awak kapal maka harus dilaksanakan fire drill. Dalam waktu satu bulan Anak buah kapal baru sudah harus menerima latihan untuk semua perlengkapan pemadam kebakaran.

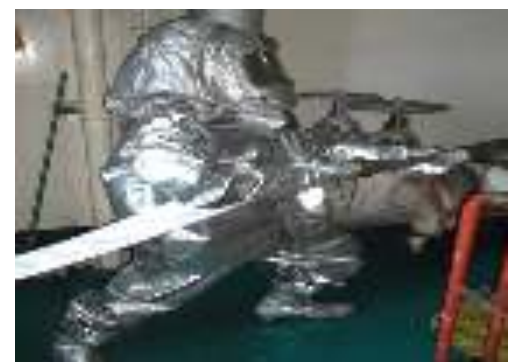

Gambar 2. Latihan Pemadaman kebakaran

Latihan pemadaman kebakaran (Fire fighting) pada kapal MT. Sepinggan yang dilakukan dititik api di daerah pumproom dengan menggunakan (Pump Man).

\section{2) Meninggalkan kapal (abandon ship)}

Anak buah kapal setiap 1 (satu) bulan sekali harus berpartisipasi dalam latihan meninggalkan kapal termasuk menjalankan sekoci dan melakukan olah gerak di atas permukaan air. Latihan ini bertujuan untuk meningkatkan keberanian anak buah kapal jika terjadi kebakaran yang besar dan harus meninggalkan kapal. Pada MT. Sepinggan satu bulan sekali melakukan

pelatihan meninggalkan kapal. Agar anak buah kapal bisa menerapkan setiap terjadi kecelakaan kapal.

3) Menggunakan sekoci

Latihan simulasi menggunakan sekoci dapat dilaksanakan bersamaan dengan latihan penggunaan peralatan atau menurunkan sekoci ke air. Pada MT. Sepinggan dilakukan sesuai arahan nakhoda.

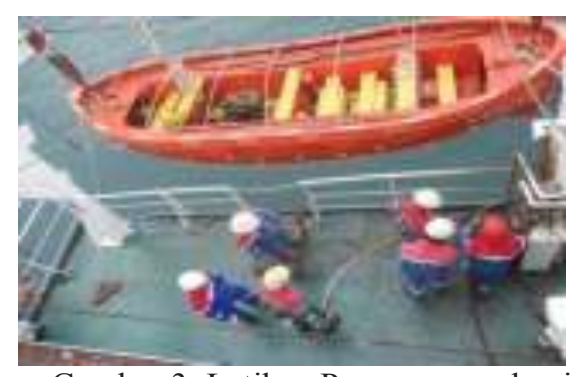

Gambar 3. Latihan Penggunaan skoci

\section{e. Bungkering (pengisian bahan bakar)}

Proses pengisian bahan bakar pada kapal melalui proses yang biasanya dilakukan secara ship to ship. Pada saat proses pengisian bahan bakar Kepala Kamar Mesin harus langsung mengawasi langsung seluruh pengoperasian pengisian bahan bakar kapal dan memastikan daftar check list pengisian sudah diisi secara benar, serta mencatat dalam Oil Record Book setelah melaksanakan pengisisan bahan bakar. Kepala kamar mesin harus memeriksa spesifikasi dari minyak yang akan dikirim menunjukkan kandungan air, kadar sulfur, dan kekentalan minyak tersebut. Sampel minyak harus diambil minimal $500 \mathrm{cc}$ ke dalam botol pengambilan contoh tersebut harus disaksikan Kepala Kamar Mesin dan pihak pemasok. Hasil contoh minyak tersebut harus dikirim ke laboratorium darat untuk dianalisa tentang 
kandungan minyak tersebut dan hasilnya dikirim ke kapal, sehubungan dengan MARPOL 73/78 Annex VI tentang pencemaran udara yang disebabkan oleh mutu dari bahan bakar yang digunakan di atas kapal. Data tersebut diperkuat oleh wawancara yang dilakukan dengan narasumber yaitu Kepala Kamar Mesin." setidaknya kami melakukan pengisian 2 minggu sekali yang dimana anak buah kapal ikut serta dalam pengisian tersebut, ada yang jaga pipa-pipa, menjaga sambungan dan lainnya, pada MT. Sepinggan kegiatan tersebut tidak diimbangi dengan upah atau tunjangan yang didapatkan". (hasil wawancara dengan Bapak Imam Paryana selaku Kepala Kamar Mesin, tanggal 12 Maret 2017).

\section{f. Pemeliharaan mesin kapal}

Pemeliharaan mesin merupakan hal yang sering dipermasalahkan pada saat ada kerusakan pada sebuah alat. Pada umumnya sebuah alat yang dihasilkan oleh manusia tidak ada yang tidak mungkin rusak, tetapi usia penggunaannya dapat diperpanjang dengan melakukan perbaikan yang dikenal dengan pemeliharaan. Oleh karena itu, sangat dibutuhkan kegiatan pemeliharaan dan perawatan mesin yang digunakan dalam kegiatan sehari-hari. Tujuan dari pemeliharaan antara lain :

1) Untuk memperpanjang asset;

2) Untuk menjamin optimalnya peralatan yang dipasang di kapal;

3) Untuk menjamin kesiapan operasional dari seluruh peralatan yang diperlukan dalam keadaan darurat setiap waktu;
4) Untuk menjamin keselamatan orang yang menggunakan sarana tersebut.

Dari hasil penelitian dapat diketahui bahwa mesin yang berada di kapal MT. Sepinggan harus bekerja terus menerus. Kegiatan perawatan pada mesin kapal MT. Sepinggan untuk mengurangi terjadinya kerusakan atau kendala terhadap mesin kapal maka harus dilakukan kegiatan perawatan rutin yang meliputi pengecekan alat-alat kapal, pengecekan pipa-pipa.

\section{- Kebijakan PT. Pertamina (Persero) mengelola fix Overtime}

a. Penghasilan / gaji

Menurut

Undang-Undang

Republik Indonesia No 8 Tahun 1974 tentang pokok-pokok kepegawaian bahwa setiap pegawai berhak memperoleh gaji yang layak sesuai dengan pekerjaan dan tanggung jawabnya. Gaji adalah balas jasa atau penghargaan atas prestasi kerja, yang harus dapat memenuhi kebutuhan hidup bersama keluarganya secara layak, sehingga dapat memusatkan perhatian dan kegiatannya untuk melaksanakan tugas yang dipercayakan kepadanya. Sistem penggajian terdapat dua sistem penggajian yaitu sistem skala tunggal dan sistem skala ganda. Sistem skala tunggal merupakan sistem penggajian yang memberikan gaji sama, tidak memperhatikan sifat pekerjaan yang dilakukan dan beratnya tanggung jawab yang dipikul dalam melaksanakan pekerjaan itu. Sistem skala ganda merupakan sistem penggajian yang menentukan besarnya gaji bukan saja didasarkan pada pangkat tetapi juga berdasarkan sifat pekerjaan yang dilakukan, prestasi kerja yang dicapai, dan beratnya tanggung jawab yang dipikul dalam melaksanakan pekerjaan itu. 
Analisis Fix Overtime Untuk Meningkatkan Kinerja Dinas Jaga ABK Kapal MT. Sepinggan Di PT. Pertamina (Persero) Perkapalan Jakarta

Andri Kurniawan, Sri Purwantini dan Arika Palapa

Tabel 1. Sistem penggajian di PT. Pertamina

\begin{tabular}{|c|c|c|}
\hline $\begin{array}{l}\text { Sistem } \\
\text { Penggajian }\end{array}$ & Keuntungan & Kerugian \\
\hline $\begin{array}{l}\text { Sistem } \\
\text { Penggajian } \\
\text { Skala } \\
\text { Tunggal }\end{array}$ & $\begin{array}{l}\text { Sederhana } \\
\text { Cukup dengan } \\
\text { satu peraturan }\end{array}$ & $\begin{array}{l}\text { Dirasa tidak adil } \\
\text { karena faktor } \\
\text { resiko bahaya, } \\
\text { kesibukan dan } \\
\text { lain-lain tidak } \\
\text { menjadikan } \\
\text { pertimbangan. }\end{array}$ \\
\hline $\begin{array}{l}\text { Sistem } \\
\text { Penggajian } \\
\text { Skala Ganda }\end{array}$ & $\begin{array}{l}\text { Memberikan } \\
\text { motivasi bagi } \\
\text { Pegawai yang } \\
\text { memikul } \\
\text { tanggung } \\
\text { jawab yang } \\
\text { berat, resiko } \\
\text { dan lain-lain. }\end{array}$ & $\begin{array}{l}\text { Menimbulkan } \\
\text { ketidakadilan } \\
\text { pada saat pensiun } \\
\text { bagi pegawai } \\
\text { yang memiliki } \\
\text { pangkat } \\
\text { pendidikan yang } \\
\text { sama tetapi } \\
\text { berbeda dengan } \\
\text { sifat pekerjaan. }\end{array}$ \\
\hline
\end{tabular}

Dari tabel 1 di atas menggambarkan bahwa sistem penggajian di PT. Pertamina (Persero) Perkapalan yang menggunakan sistem penggajian ganda bagi setiap pegawai yang memikul tugas dan peranan, karena tugas dan tanggung jawab di kapal yang berat dan resiko yang sangat tinggi. Maka kebijakan penggajian sistem ganda yang ditetapkan oleh PT. Pertamina (Persero) sangat tepat. Sehingga Anak buah kapal akan merasa dihargai mengenai peranan yang mereka lakukan.

\section{b. Pemberian insentif dan \\ kompensasi}

Menurut Supartini (2010), insentif adalah bonus atas prestasi luar biasa yang dicapai bawahan. Insentif merupakan penghargaan dalam bentuk uang yang diberikan kepada mereka yang dapat bekerja melampaui standar yang telah ditentukan. Tujuan pemberian insentif adalah untuk memberikan tanggung jawab dan dorongan kepada karyawan. Insentif menjamin bahwa karyawan akan mengarahkan usahanya untuk mencapai tujuan. Sedangkan tujuan utama pemberian insentif adalah untuk meningkatkan produktivitas kerja individu maupun kelompok. Pada PT. Pertamina Perkapalan menerapkan 2 (dua) insentif yaitu finansial insentif dan finansial non insentif. Finansial insentif pada PT. Pertamina bersifat keuangan yang bukan saja meliputi gaji-gaji yang pantas. Tetapi juga termasuk didalamnya kemungkinan memperoleh bagian dari keuntungan perusahaan dan soal-soal kesejahteraan yang meliputi pemeliharaan jaminan hari tua, rekreasi dan kesehatan. Sedangkan non finansial insentif di PT. Pertamina meliputi tempat kerja, jam kerja, tugas dan rekan kerja ataupun sikap pemimpin terhadap keinginan masing-masing karyawan seperti jaminan pekerjaan, promosi jabatan, keluhan-keluhan, hiburan-hiburan dan hubungan dengan atasan. Sehubungan dengan promosi jabatan PT. Pertamina juga memberlakukan pengangkatan jabatan di atas kapal yang direkomendasikan oleh Nakhoda sebagai jaminan atau balas jasa yang dilakukan oleh anak buah kapal terhadap kinerja dinas jaga yang baik. Promosi ini didukung dengan kurangnya jabatan anak buah kapal pada kapal-kapal milik PT. Pertamina Perkapalan. Data tersebut dapat dilihat dari promosi jabatan sebagai berikut:

Tabel 2. Promosi jabatan PT. Perkapalan

\begin{tabular}{|l|c|c|c|c|c|}
\hline \multicolumn{1}{|c|}{ Jabatan } & ABK & On & Off & $\begin{array}{c}\text { kebut } \\
\text { uhan }\end{array}$ & $\begin{array}{c}\text { kekura } \\
\text { ngan }\end{array}$ \\
\hline Bosun & 89 & 68 & 21 & 24 & 17 \\
\hline Pumpman & 92 & 72 & 23 & 25 & 17 \\
\hline Able & 246 & 195 & 51 & 78 & 58 \\
\hline ordinary & 223 & 169 & 54 & 51 & 0 \\
\hline
\end{tabular}


Dari tabel 2 di atas menunjukkan bahwa jabatan Bosun kurang 17 (tujuh belas) orang, jabatan Juru Pompa kurang 17 (tujuh belas) orang, jabatan Juru Mudi kurang 54 (lima puluh empat) orang dan kelasi 0 (nol). kebutuhan Bosun, Juru Pompa, Juru mudi sangat kurang. Sedangkan promosi yang dilakukan masih sangat kurang. Maka kekurangan promosi pada masing-masing jabatan ditindak lanjuti oleh PT. Pertamina (Persero) Perkapalan.

\section{c. Vassel allowence}

Vassel allowence merupakan kebijakan perusahaan yang diterapkan di atas kapal untuk meningkatkan kinerja Anak buah kapal. Pemberian vassel allowence berdasarkan jabatan dan ukuran kapal. kegiatan yang dilakukan oleh Anak buah kapal, seperti membersihkan tangki-tangki minyak, kegiatan tersebut dilakukan berdasarkan perintah dari Mualim I Chief Officer karena tugas dan tanggung jawab dari Mualim I adalah pemeliharaan deck meliputi tanki muatan, ruang muat, kamar pompa, pipa, katup, katup PV valve, manifold, oleh karena itu Mualim 1 yang berhak memerintah anak buahnya untuk melakukan perawatan deck untuk menjaga tangki-tangki tetap bersih. Pada MT. Sepinggan, penerapan vassel allowance berdasarkan jabatan dan ukuran kapal sudah dibenarkan oleh pihak HRD "vessel allowence di atas kapal MT. Sepinggan kita sudah menerapkan dengan baik, kita membayarkan vassel allowence sesuai jabatan dan ukuran kapal" (hasil wawancara dengan Ibu Diza selaku Sekretaris HRD, tanggal 12 Maret 2017)

\section{KESIMPULAN}

\section{A. Kesimpulan}

Berdasarkan pembahasan yang telah dikemukakan dalam bab-bab sebelumnya mengenai menurunnya kinerja dinas jaga ABK MT. Sepingan, maka dapat ditarik kesimpulan diantaranya:

1. Faktor-faktor penyebab munculnya Fix Overtime pada kapal MT. Sepinggan PT. Pertamina (Persero) perkapalan Jakarta yaitu peran muka belakang ketika sandar atau lepas sandar, adanya lego jangkar, adanya bongkar muat muatan, adanya Drill, adanya Bungkering (pengisian bahan bakar), pemeliharaan mesin kapal.

2. Kebijakan PT. Pertamina (Persero) Perkapalan Jakarta mengelola Fix Overtime pada MT. Sepinggan yaitu penghasilan atau gaji, pemberian insentif dan kompensasi, Vessel allowance.

\section{B. Saran}

Sebagai langkah perbaikan di masa mendatang, peneliti menyarankan beberapa hal yang diharapkan dalam pelaksanaan dinas jaga dapat berjalan secara optimal, untuk menghindari halhal tersebut di atas, sebagai berikut :

1. Kapten kapal MT. Sepinggan hendaknya memberikan motivasi kepada para Anak buah Kapal MT. Sepinggan sehingga ABK Kapal MT. Sepinggan dapat menjaga pola dan ritme kerjanya. Alhasil kinerja ABK Kapal MT. Sepinggan tidak terjadi penurunan meskipun adanya fix overtime.

2. PT Pertamina Persero hendaknya menerapkan kebijakan mengenai Overtime anak buah kapal dan memberikan sosialisasi mengenai overtime kepada ABK Kapal MT. Sepinggan sehingga tercipta pemahaman mengenai kebijakan 
Analisis Fix Overtime Untuk Meningkatkan Kinerja Dinas Jaga ABK Kapal MT. Sepinggan Di PT.

Pertamina (Persero) Perkapalan Jakarta

Andri Kurniawan, Sri Purwantini dan Arika Palapa

tersebut dan kinerja ABK Kapal MT.

Sepinggan tetap terjaga.

\section{DAFTAR PUSTAKA}

Arikunto, S. 2010. Prosedur Penelitian : Suatu Pendekatan Praktik. (Edisi Revisi). Jakarta : Rineka Cipta

Colonna, S. B. 2007, Pengembangan Komitmen pada Mutu Bahan untuk Mahasiswa, Asosisi Politeknik Indonesia

Daryanto. 2010. Media Pembelajaran. Yogyakarta: Gava Media

Harianto, F., Syafiudin, M. 2008. Perbandingan Produktifitas kerja lembur dan kerja normal di proyek rehabilitasi terminal joyoboyo Surabaya. Jurnal IPTEK, Vol 11(1)

Indraputra, T., Sutrisna, E. 2013. Disiplin, motivasi, budaya kerja, dan kinerja. Jurnal administrasi pembangunan, vol 1(3), 219-323

Krisdiana. 2007. analisis pengaruh kepuasan kerja dan motivasi terhadap kinerja karyawan dengan momitmen organisasional sebagai variable intervening (studi pada karyawan oursourcing), Disertasi. Program Pasca Sarjana Universitas Diponegoro, Semarang

Mathan, D. S., Achnes, S. 2013. Kompensasi, Motivasi Kerja, dan kinerja pegawai. Jurnal administrasi pembangunan, vol 2 (1), 1-114

Moeis, S. 2008. Kekuasaan, Wewenang dan Kepemimpinan, Makalah, Universitas Pendidikan Bandung

Peraturan Menteri Tenaga Kerja dan Transmigrasi Republik Indonesia
No. Kep. 102/MEN/VI/2004

Tentang Waktu Kerja Lembur dan Upah Kerja Lembur.

Peraturan Pemerintah Republik Indonesia Nomor 11 Tahun 1975 Tentang Keselamatan Kerja Terhadap Radiasi

Pratiwi, W. Efektifitas Penggunaan Pembelajaran Student Teams Achievement Division (STAD) dan Group Investigation (GI) Ditinjau dari Presentasi Belajar IPS pada Siswa Kelas IV di SD Kasihan Bantul. Jurnal Penelitian

Salim, Peter dan Yenny Salim. 2002. Kamus Bahasa Indonesia Kontemporer. Jakarta: Modern English Press

Setiono, B. A. 2010. Pengaruh Safety Equipment Terhadap Keselamatan Berlayar. Jurnal Aplikasi Pelayaran dan Kepelabuhanan, Vol 1(1)

Subandrio, D. 2015. Tugas Jaga. Semarang

Sugiyono. 2009. Metode Penelitian Kuantitatif, Kualitatif, dan $R \& D$. Bandung : Alfabeta

Sugiyono. 2015. Metode Penelitian Kuantitatif, Kualitatif, dan $R \& D$, CV Alfabeta: Bandung

Supartini. 2010. Motivasi Guna Peningkatan Prestasi Kinerja Bawahan di Perusahaan Pelayaran. Jurnal Penelitian

Undang-Undang Republik Indonesia No. 17 Tahun 2008 tentang Pelayaran

Undang-Undang Republik Indonesia No. 8 Tahun 1974 tentang pokok-pokok Kepegawaian 